\title{
Documentation of ethno-medicinal practices: A case study on tribal forest fringe dwellers of Terai West Bengal in India
}

\author{
A. N. Dey, S. Datta ${ }^{1^{*}}$ and Bani Sharma \\ Department of Forestry, Uttar Banga Krishi Viswavidyalaya, Pundibari, Cooch Behar-736165 (West Bengal), \\ INDIA \\ ${ }^{1}$ Regional Research Station, Terai Zone, Uttar Banga Krishi Viswavidyalaya, Pundibari, Cooch Behar-736165 \\ (West Bengal), INDIA \\ *Corresponding author. E-mail: suchanddatta@gmail.com
}

Received: December 3, 2014; Revised received: August 30, 2015; Accepted: October 14, 2015

\begin{abstract}
The ethno-medicinal practices were documented which were being used by tribal population dwelling forest fringe areas of Terai zone of West Bengal, India on under exploited, non conventional, traditional and indigenous plant species for the sustainable utilization of these resources to cure day to day ailments. A total number of forty seven medicinal plant species belonging to 25 families were documented during the survey period 2012-13, which was used in curing many diseases. Among the families, Euphorbiaceae, Zingeberaceae and Leguminosae were the dominant families that represented four species each. Herb was the highest proportion of plant species 18 $(38 \%)$ followed by 15 tree species (32\%), 8 species of shrubs $(17 \%)$ and rest were climbers and fern. It was observed that the tribal forest fringe communities of the Terai zone of the West Bengal have a good ethno-medicinal knowledge of using plant resources and developed their own traditional practices to cure day to day diseases.
\end{abstract}

Keywords: Ailments, Medicinal plant, Sub-himalayan tract, Traditional medicines

\section{INTRODUCTION}

Over the centuries the use of medicinal plants based traditional medicines has become an important part of daily life despite the progress in modern medical and pharmaceuticals research because of the side effects of synthetic drugs, the failure of primary healthcare services to cover rural population and spiraling cost of the common drugs (Tiwari, 1999). The importance of traditional medicine as a source of primary health care was first officially recognized by World Health Organization (WHO) in 1978. This kind of health care is traditionally accepted because of easy accessibility, low cost, elaborate patient healer interaction, long term family association, friendly attitude of healer and so on (Lamba and Mehta, 1995). Over 80 percent of the world's population depends directly on plant based medicine for their health care (WHO, 2003). The WHO has described traditional medicine as one of the surest means to achieve total health care coverage of the world's population. Ethno-medicine refers to the study of traditional medical practice which is concerned with the cultural interpretation of health, diseases and illness and also addresses the healthcare seeking process and healing practices of people (Krippner, 2003). More than 20,000 species of higher plants are used as medicines in the traditional treatment practices of indigenous cultures living around the world. In India it is reported that traditional healers use
2500 plant species and medicine (Pei, 2001). The documentation of indigenous knowledge on the utilization of local plant resources by different ethnic groups or communities is one of the main objectives of ethnobotanical research (Shrestha, 1998).

A number of workers investigated the number of plants for their medicoreligious properties of plants as reported by Ranta and Pirata (2007), Singh and Singh (2008) and Sharma and Joshi (2010). The plant diversity has been used by different communities for various purposes such as food, fodder, fuel, medicine, religious and other purposes (Kumar, 2013 and Dangwal et al. 2014). Popularity of plant species are declining continuously due to increasing of the demand for other food products and medicinal values. Hence, resulted the degradation of traditional knowledge about the ethnomedicinal values. These genetic resources of forest plant species should be conserved for future use to overcome malnutrition in vegetarian diet and livelihood of the rural as well as tribal communities. So, the survey of the tribal areas for documentation of underutilized plants species is the first step for the conservation and sustainable utilization of these resources to maintain the traditional system of health care system for the population dwelling in forest fringe areas. The present study deals with the indigenous knowledge related with ethnomedicinal uses of plants used by the tribal people of the forest fringe areas of Terai, West Bengal which is a rich repository of diversified medici- 
nal plant species, especially in the forest areas of Eastern Sub-Himalayan Tract because of the varied biogeographical zones and climatic conditions. The main objective of this study is to identify, explore indigenous/traditional knowledge and document existing practices on use of common medicinal plants for the treatment of diseases.

\section{MATERIALS AND METHODS}

Study area: The study was conducted in four villages namely, Medabari and Rava basti village of Chilapata Forest Range and Baishmile and Pampu Basti village of the Rajabhatkhawa Forest Range of West Bengal during 2012 - 13. The Chilapata Forest Range (latitude $26^{\circ} 32^{\prime} \mathrm{N}$ and longitude $89^{\circ} 22^{\prime} \mathrm{E}$; altitude $90 \mathrm{~m} \mathrm{msl}$ ) is $20 \mathrm{~km}$ from Pundibari in Soth-western direction under Cooch Behar Forest Division with adjoining areas of Cooch Behar, Jalpaiguri and Bhutan. Rajabhatkhawa Forest range (latitude $26^{\circ} 36^{\prime} \mathrm{N}$ and longitude $89^{\circ} 40^{\prime} \mathrm{E}$; altitude $120 \mathrm{~m} \mathrm{msl}$ ) under Jalpaiguri Forest Division, a part of Buxa Tiger Reserve which is $40 \mathrm{kms}$ away from Pundibari.

The inhabitants of the survey area under Rajabhatkhawa forest range comprise about the different communities of the scheduled tribe namely, 35\% Santhals, 30\% Rava, 2\% Metch and rest 33\% Rajbanshi. The majority of the population $(>80 \%)$ in the survey area under Chilapata forest range comprised two different communities of the scheduled tribe namely, Ravas and Oraons. It was found from the survey that collecting minor forest products including medicinal plants are one of the important sources of livelihood of the targeted population. For subsistence, they also practice agriculture, piggery, poultry, dairy and goat rearing.

Data was collected through a combinations of tools and techniques of the questionnaires, Participatory Rural Appraisal (PRA) technique, focused group interview and discussion among 100 people from four villages (25 people per village). Information on curative values as well as medicinal values of different plant species were gathered through the personal interview. The local names of the plants and folklore claims of the respective uses were verified by showing the same specimen to the elder people and cross checking was finally confirmed after consultation with herb healers and ayurvedic practioners of the same locality.

\section{RESULTS AND DISCUSSION}

During the survey period about 47 plant species were documented and are presented in table 1. It was observed that among all the life forms, 18 herbs namely, Achyranthus aspera L., Acorus calamus L., Adhatoda vasica Nees, Andrographis paniculata Wall.ex Nees, Centella asiatica L., Curcuma caesia Roxb., Curcuma longa L., Datura metel L., Elettaria cardamomum Maton, Emblica officinalis, Eupatorium ayapana Vent., Euphorbia hirta L., Leucus aspera (Willd.), Piper longum L., Polygonum dichrotomum Blume, Saussurea lappa C.B.Clarke, Solanum xanthocarpum

Table. 1. List of the important medicinal plants.

\begin{tabular}{|c|c|c|c|c|}
\hline S.N. & Scientific name & Common name & Family & Habit \\
\hline 1 & A. vasica & Vasaka & Acanthaceae & Herb \\
\hline 2 & A. paniculata & Kalmegh & Acanthaceae & Herb \\
\hline 3 & A. aspera & Apang/Apamarg & Amaranthaceae & Herb \\
\hline 4 & L. coromondelica & Geol/Jiga & Anacardiaceae & Tree \\
\hline 5 & A. scholaris & Chatim & Apocynaceae & Tree \\
\hline 6 & A. calamus & Bach & Araceae & Herb \\
\hline 7 & C. gigantean & Akanda & Asclepidiaceae & Shrub \\
\hline 8 & O. indicum & Totala & Bignoniaceae & Tree \\
\hline 9 & T. arjuna & Arjuna & Combretaceae & Tree \\
\hline 10 & T. bellirica & Bahera & Combretaceae & Tree \\
\hline 11 & T. chebula & Haritaki & Combretaceae & Tree \\
\hline 12 & E. ayapana & Bisalyaka rani/Ayapan & Compositae & Herb \\
\hline 13 & S. lappa & Kur & Compositae & Herb \\
\hline 14 & E. officinalis & Amloki & Euphorbiaceae & Tree \\
\hline 15 & E. hirta & Lal Dudhi & Euphorbiaceae & Herb \\
\hline 16 & J. curcas & Varenda & Euphorbiaceae & Shrub \\
\hline 17 & R. communis & Arenda & Euphorbiaceae & Shrub \\
\hline 18 & C. asiatica & Thankuni/Manimuni & Hydrocotylaceae & Herb \\
\hline 19 & L. aspera & Dandakalas & Labiatae & Herb \\
\hline 20 & O. sanctum & Tulsi & Labiatae & Shrub \\
\hline 21 & C. fistula & Amaltas/Sondal & Leguminosae & Tree \\
\hline 22 & M. pruriens & Alkusi & Leguminosae & Climber \\
\hline 23 & S. indica & Ashoka & Leguminosae & Tree \\
\hline 24 & S. bisponosa & Jayanti & Leguminosae & Tree \\
\hline 25 & A. wallichii & Lali & Meliaceae & Tree \\
\hline
\end{tabular}


Table 1. Contd.

\begin{tabular}{lllll}
\hline 26 & A. indica & Neem & Meliaceae & Tree \\
27 & S. herandifolia & Nimoko & Menispermaceae & Climber \\
28 & T. cordifolia & Gulancha & Menispermaceae & Climber \\
29 & M. fragrans & Jaiphal/Jaitri & Myristicaceae & Tree \\
30 & P. guajava & Peyara & Myrtaceae & Tree \\
31 & H. indicus & Anantamul & Periplocaceae & Shrub \\
32 & P. longum & Pipali & Piperaceae & Herb \\
33 & P. nigrum & Gol marich & Piperaceae & Climber \\
34 & P. retrofactum & Choi & Piperaceae & Climber \\
35 & P. dichrotomum & Biskathali & Polygonaceae & Herb \\
36 & A. marmelos & Bael & Rutaceae & Tree \\
37 & D. metel & Kalo Dhatura & Solanaceae & Herb \\
38 & S. xanthocarpum & Kantakari & Solanaceae & Herb \\
39 & W. somnifera & Aswagandha & Solanaceae & Shrub \\
40 & C. dentate & Bisdhenkia & Thelypteridaceae & Fern \\
41 & C. indicum & Bamunhati & Verbenaceae & Shrub \\
42 & V. nigundo & Nisindha & Verbenaceae & Shrub \\
43 & C. caesia & Kali haldi & Zingeberaceae & Herb \\
44 & C. longa & Haldi & Zingeberaceae & Herb \\
45 & E. cardamomum & Chota ellachi & Zingeberaceae & Herb \\
46 & Z. officinale & Adha/Adrak & Zingeberaceae & Herb \\
47 & T. terrestris & Gokhur kanta & Zygophllaceae & Herb \\
\hline
\end{tabular}

Schrad \& Wendl., Tribulus terrestris L., Zingeber officinale Rosc., 15 trees namely, Aegle marmelos (L.) Corr., Alstonia scholaris (L.) R.Br., Amoora wallichii King, Azadirchta indica A. Juss, Cassia fistula L., Emblica officinalis Gaertn, Lannea coromondelica (Houtt.) Merr., Myristica fragrans Houtt., Oroxylum indicum L., Psidium guajava L., Saraca indica Auct. non L., Sesbania bisponosa (Jacq.) W.F. Wight, Terminalia arjuna (Roxb.) Wight \& Arn., Terminalia bellirica (Gaertn.) Roxb., Terminalia chebula Retz., 8 shrubs namely, Calotropis gigantean Ait., Clerodendron indicum (L.) Kuntze, Hemidesmus indicus (L.) Schult., Jatropha curcas L., Ocimum sanctum L., Ricinus communis L., Vitex nigundo L., Withania somnifera L., 5 climbers (namely, Mucuna pruriens L., Piper nigrum L., Piper retrofactum Vahl., Stephania herandifolia Walp., Tinospora cordifolia Willd. and 1 fern specie namely, Christella dentate (Forssk.) Brownsey \& Jermy were used by the tribal population for their health care. These life forms belonged to 25 families, among which Euphorbiaceae, Leguminoseae and Zingeberaceae were the dominant with four species each followed by Piperaceae, Solanaceae and Combretaceae. Earlier, Behera and Nayak (2012) have reported 44 wild plant species belonging to 30 families and 36 genera that are most used by the Kandha and Kolha tribes for treatment different diseases and disorder where as Kalita and Phukan (2010) have mentioned 24 different plant species were used traditionally by the Tai Ahom people of Dibrugargh district of Assam. Large numbers of medicinal plants are reported to be abortifacient, analgesic, antiseptic antibulous, astringent, antipyretic etc. and are used in traditional system of health care (Jain, 1991; Acharya, 2012; Kumar, 2013 and Dangwal et al, 2014 ). The findings of the present work are similar with the findings of the above workers.

Diseases like indigestion, cough, cold, asthma, heart problems, skin diseases, weakness, rheumatism, dysentery etc. are cured by these plants and are found to be very effective when taken in proper doses. Respective uses and doses were verified by consultation with herb healers and ayurvedic practioners of the same locality. The mode of preparation and the doses of the medicines prepared from the plant parts were collected from the respondents and other various secondary sources are represented in table 2 . It was found that among the plant parts leaves of most of the plant species were widely used for the treatment. The leaves of 17 species were being used by the tribal population for more than 100 years..

\section{Conclusion}

It was observed that the tribal communities have a good ethno-medicinal knowledge of using plant resources and developed their own traditional practices to cure day to day diseases. Besides this information, the data provides the glimpses of light for further scientific investigation of principal active compounds which are responsible for curative properties of these plant species.

\section{REFERENCES}

Acharya, R. (2012). Ethnobotanical study of medicinal plants of Resunga hill used by Magar Community of Badagaun VDC, Gulmi district, Nepal. Scientific World, 10 
Table. 2. Plant parts used to cure different diseases along with mode of preparation and dosages.

\begin{tabular}{|c|c|c|c|c|}
\hline S.N. & Scientific name & Parts used & Diseases cured & Mode of preparation and dosage \\
\hline 1 & A. aspera & Root & $\begin{array}{l}\text { Indigestion and dys- } \\
\text { entery }\end{array}$ & Half cup of root decoction once a day. \\
\hline 2 & A. calamus & Rhizome & $\begin{array}{l}\text { Indigestion and } \\
\text { overfullness }\end{array}$ & Rhizome powder taken with hot water. \\
\hline 3 & A. vasica & Leaf & Cough and cold & $\begin{array}{l}\text { A mixture of powdered form of Piper } \\
\text { longum }(0.61 \mathrm{~g}) \text { along with one teaspoon- } \\
\text { ful leaf juice each of Adhatoda vasica and } \\
\text { Ocimum sanctum. }\end{array}$ \\
\hline 4 & A. marmelos & Leaf, fruit & $\begin{array}{l}\text { Indigestion and con- } \\
\text { stipation }\end{array}$ & $\begin{array}{l}\text { Fruit plup mixed with water taken for } 3-7 \\
\text { days or } 3-5 \text { bael leaves taken in the morn- } \\
\text { ing. }\end{array}$ \\
\hline 5 & A. scholaris & Bark & White pigmentation & $\begin{array}{l}\text { Bark powder to be applied on the affected } \\
\text { areas. }\end{array}$ \\
\hline 6 & A. wallichii & Fruit & $\begin{array}{l}\text { Improving weakness } \\
\text { after delivery }\end{array}$ & $\begin{array}{l}\text { Fruits boiled with water thereafter } \\
\text { crushed, dried and powdered and taken. }\end{array}$ \\
\hline 7 & A. paniculata & Leaf, twigs & $\begin{array}{l}\text { Improve liver func- } \\
\text { tion }\end{array}$ & $\begin{array}{l}\text { Extracts have showed protection on liver } \\
\text { from various chemicals such as carbon } \\
\text { tetrachloride. }\end{array}$ \\
\hline 8 & A. indica & Leaf, stem & Dental problems & $\begin{array}{l}\text { Leaves and stem are rubbed against the } \\
\text { teeth. }\end{array}$ \\
\hline 9 & C. gigantean & Leaf, latex & Skin diseases & Latex is rubbed on the itching areas. \\
\hline 10 & C. fistula & Leaf & Hepatoprotection & $\begin{array}{l}\text { The extract at a dose of } 400 \mathrm{mg} / \mathrm{kg} \text { body } \\
\text { wt. when taken orally lowers bilirubin and } \\
\text { alkaline phosphatase (ALP) in liver. }\end{array}$ \\
\hline 11 & C. asiatica & Leaf & Dysentery & $\begin{array}{l}\text { Juice extract should be taken in empty } \\
\text { stomach at early morning }\end{array}$ \\
\hline 12 & C. dentate & Leaf & Cuts and wounds & $\begin{array}{l}\text { Leaf extract used for immediate recovery } \\
\text { from bleeding of cuts and wounds }\end{array}$ \\
\hline 13 & C. indicum & Root & $\begin{array}{l}\text { Cold, cough and } \\
\text { asthamatic problem }\end{array}$ & $\begin{array}{l}\text { Powdered form of } 10 \mathrm{~g} \text { each of Piper ni- } \\
\text { grum, P. longum, Zingiber officinale, } \\
\text { Clerodendron indicum, roots of Saussurea } \\
\text { lappa and Piper retrofractum used for } \\
\text { partial relief from asthma. }\end{array}$ \\
\hline 14 & C. caesia & Rhizome & Rheumatism & $\begin{array}{l}\text { Paste of rhizome applied in the affected } \\
\text { area for partial relief. }\end{array}$ \\
\hline 15 & C. longa & Rhizome & $\begin{array}{l}\text { Skin diseases, jaun- } \\
\text { dice }\end{array}$ & $\begin{array}{l}\text { Paste of Curcuma longa and Curcuma } \\
\text { caesia with mustard oil is very effective. } \\
\text { Powder mixed with curd taken internally } \\
\text { for jaundice. }\end{array}$ \\
\hline 16 & D. metel & Leaf & Asthma & $\begin{array}{l}\text { Leaf dust smoked with cow dung cake is } \\
\text { effective for immediate relief }\end{array}$ \\
\hline 17 & E. cardamomum & Capsule & $\begin{array}{l}\text { Vitality and weak- } \\
\text { ness }\end{array}$ & $\begin{array}{l}\text { One teaspoonful mixture of Piper nigrum, } \\
P \text {. longum, Myristica fragrans and Elet- } \\
\text { taria cardamomum with honey or milk } \\
\text { once at bed time. }\end{array}$ \\
\hline 18 & E. officinalis & Fruit & Scabies & $\begin{array}{l}\text { Paste prepared by mixing } 100 \mathrm{~g} \text { fruit pow- } \\
\text { der along with coconut oil and applied for } \\
3 \text { days. }\end{array}$ \\
\hline 19 & E. ayapana & Leaf & Cut and wounds & $\begin{array}{l}\text { Leaves crushed and applied externally on } \\
\text { the wounds to check bleeding. }\end{array}$ \\
\hline 20 & E. hirta & Whole plant & Piles & $\begin{array}{l}4 \text { teaspoonfuls of bark decoction taken } \\
\text { orally twice a day after meals. }\end{array}$ \\
\hline 21 & H. indicus & Root & Asthma & $\begin{array}{l}\text { Roots mixed with milk given thrice daily } \\
\text { for seven days. }\end{array}$ \\
\hline
\end{tabular}


Table 2. Contd.....

\begin{tabular}{|c|c|c|c|c|}
\hline 22 & J. curcas & Seed, root & Dental problems & Rubbing teeth with the stem is effective. \\
\hline 23 & L. coromondelica & $\begin{array}{l}\text { Gum (exudates } \\
\text { from stem bark) }\end{array}$ & Piles & $\begin{array}{l}\text { The gum is fried thoroughly and ground } \\
\text { and mixed with water and made into pills. }\end{array}$ \\
\hline 24 & L. aspera & Leaf, twigs & Body pain & $\begin{array}{l}\text { Leaves taken as vegetable is useful against } \\
\text { bodyache. }\end{array}$ \\
\hline 25 & M. pruriens L. & Seed & $\begin{array}{l}\text { Vitality and weak- } \\
\text { ness }\end{array}$ & $\begin{array}{l}\text { Seeds boiled with milk for purification } \\
\text { thereafter seeds are dried and powdered. }\end{array}$ \\
\hline 26 & M. fragrans & Fruit & Cold, cough & $\begin{array}{l}\text { Very small dose of the fruit extract is taken } \\
\text { orally. }\end{array}$ \\
\hline \multirow[t]{2}{*}{27} & O. sanctum & Leaf & $\begin{array}{l}\text { Cold, cough, ash- } \\
\text { tamatic and dental } \\
\text { problem }\end{array}$ & $\begin{array}{l}\text { Tea of leaves along with Piper nigrum is } \\
\text { prepared and taken orally for coug,cold and } \\
\text { asthma. }\end{array}$ \\
\hline & & & & $\begin{array}{l}\text { Dried Zingiber officinale enclosed with } \\
\text { Ocimum sanctum leaves gives relief in case } \\
\text { of toothache. }\end{array}$ \\
\hline 28 & O. indicum & Bark & Jaundice & $\begin{array}{l}\text { Bark soaked in water overnight and the } \\
\text { extract taken early in the morning is effec- } \\
\text { tive. }\end{array}$ \\
\hline 29 & P. longum & Seed & $\begin{array}{l}\text { Cough, sore on } \\
\text { tongue }\end{array}$ & $\begin{array}{l}3 \text { to } 4 \text { seeds mixed with honey and taken } \\
\text { orally. }\end{array}$ \\
\hline 30 & P. nigrum & Seed & Rheumatism & $\begin{array}{l}20 \mathrm{~g} \text { each of Piper nigrum, Piper longum } \\
\text { dried Zingiber officinale, Ricinus communis } \\
\text { (roots) and Vitex negundo (leaves) boiled } \\
\text { with } 1 \text { litre of water and finally to come } \\
250 \mathrm{ml} \text { (i.e. decoction form). From this } 2 \mathrm{ml} \\
\text { decoction is taken twice a day (morning } \\
\text { and evening). }\end{array}$ \\
\hline 31 & P. retrofactum & Stem & $\begin{array}{l}\text { Cold, cough and } \\
\text { asthamatic prob- } \\
\text { lems }\end{array}$ & $\begin{array}{l}\text { One teaspoonful mixture og equal quanti- } \\
\text { ties of Trikadu (i.e.a mixture of equal quan- } \\
\text { tities of Piper nigrum, Piper longum and } \\
\text { Zingiber officinale) and Piper retrofractum } \\
\text { is taken with honey in empty stomach at } \\
\text { morning. }\end{array}$ \\
\hline 32 & P. dichrotomum & $\begin{array}{l}\text { Leaf, tender } \\
\text { shoot }\end{array}$ & Dental problems & $\begin{array}{l}\text { Rinsing of mouth with a solution prepared } \\
\text { from } 250 \mathrm{~g} \text { leaves and tender stem mixed } \\
\text { with } 10 \mathrm{gm} \text { of alums boiled with } 1 \text { litre of } \\
\text { water uoto final volume of } 500 \mathrm{ml} \text { water for } \\
2-3 \text { times in a day in case of adult. }\end{array}$ \\
\hline 33 & P. guajava & Leaf, shoot tip & Indigestion & $\begin{array}{l}\text { Juice extract from equal quantities of } \\
\text { crushed Psidium guajava and fresh Termi- } \\
\text { nalia arjuna used against indigestion. }\end{array}$ \\
\hline 34 & R. communis & Root & $\begin{array}{l}\text { Lumbago and } \\
\text { sciatica }\end{array}$ & $\begin{array}{l}\text { A decoction of the roots is used in the treat- } \\
\text { ment. }\end{array}$ \\
\hline 35 & S. indica & Bark & $\begin{array}{l}\text { Vitality and weak- } \\
\text { ness }\end{array}$ & $\begin{array}{l}\text { Half cup ( } 125 \mathrm{ml} .) \text { of bark decoction taken } \\
\text { twice a day or } 7 \text { days. }\end{array}$ \\
\hline 36 & S. lappa & Root & $\begin{array}{l}\text { Respiratory disor- } \\
\text { ders }\end{array}$ & $\begin{array}{l}\text { The dried roots are macerated in warm wa- } \\
\text { ter then the oil is extracted which is effec- } \\
\text { tive in relaxing bronchial muscles. }\end{array}$ \\
\hline 37 & S. bisponosa & Leaf & Eczema & Use of leaf paste externally is effective. \\
\hline 38 & S. xanthocarpum & Root & Cold and cough & $\begin{array}{l}\text { Four teaspoonfuls of root decoction once a } \\
\text { day for seven days to cure cold and cough. }\end{array}$ \\
\hline 39 & S. herandifolia & Leaf & $\begin{array}{l}\text { Indigestion and } \\
\text { dysentery }\end{array}$ & $\begin{array}{l}\text { Half cup of juice extract from leaves taken } \\
\text { once a day on empty stomach at early } \\
\text { morning. }\end{array}$ \\
\hline
\end{tabular}




\begin{tabular}{|c|c|c|c|c|}
\hline 40 & T. arjuna & Bark & Heart diseases & $\begin{array}{l}\text { Bark extract at doses of } 500 \mathrm{mg} \text { every } 8 \text { hours for up } \\
\text { to } 3 \text { months }\end{array}$ \\
\hline 41 & T. bellirica & Fruit & $\begin{array}{l}\text { Cough, cold, asthma } \\
\text { disease }\end{array}$ & $3-6$ gm of fruit powder taken daily \\
\hline 42 & T. chebula & Fruit & Rheumatism & $\begin{array}{l}\text { Decoction of trifala (i.e.a mixture of equal quantities } \\
\text { of Terminalia chebula, T. bellerica and Emblica offi- } \\
\text { cinalis) is prepared and four teaspoonfuls taken once } \\
\text { a day. }\end{array}$ \\
\hline 43 & T. cordifolia & Stem & $\begin{array}{l}\text { Rheumatism, jaun- } \\
\text { dice }\end{array}$ & $\begin{array}{l}\text { Stems boiled with sesame oil @ 1:5 ratio until froth- } \\
\text { ing will stop. Massage with this oil gives relief } \\
\text { 1-2 teaspoon juice extract from fresh stem and honey } \\
\text { for rapid cure of jaundice. }\end{array}$ \\
\hline 44 & T. terrestris & Fruit & Male sterility & $\begin{array}{l}\text { About } 4 \text { gm powder given twice a day with milk and } \\
\text { honey. }\end{array}$ \\
\hline 45 & V. nigundo & Leaf & Arthritis & $\begin{array}{l}\text { Essential oils from leaves are applied to the affected } \\
\text { area. }\end{array}$ \\
\hline 46 & W. somnifera & Root & Impotency & $\begin{array}{l}\text { About } 4 \text { gm powder given twice daily (morning and } \\
\text { at night before going to bed) with milk. }\end{array}$ \\
\hline 47 & Z. officinale & Rhizome & $\begin{array}{l}\text { Cold and flu, loose } \\
\text { motion of children }\end{array}$ & $\begin{array}{l}\text { A mixture of dry Zingiber officinale, leaves of Cassia } \\
\text { fistula and sugar or simply hot Zingiber officinale } \\
\text { drink is highly effective. } \\
\text { Rhizome taken with honey is effective in loose mo- } \\
\text { tion in children. }\end{array}$ \\
\hline
\end{tabular}

Source : Respondents from survey areas and herb healers and ayurvedic practioners of the same locality.

(10) : 55-65.

Behera, M.C. and Nayak, S. (2012). Phytotherapeutic claims of Kandha and Kolha tribes of district Boudha (Orissa). The Indian Forester, 138 (4):313-318.

Dangwal, L.R., Singh, T. and Singh, A. (2014). Exploration of wild edible plants used by Gujar and Bakerwal tribes of district Rajouri (J\&K), India. Journal of Applied and Natural Sciences, 6(1): 164-169.

Jain, S.K. (1991). Dictionary of Indian Folk Medicine and Ethnobotany. Deep Publications, New Delhi.

Kalita, D. and Phukan, B. (2010). Some ethnomedicines used by the Tai Ahom of Dibrugarh district, Assam, India. Indian J. Natural Products and Resources, 1(4): 507511.

Krippner, S. (2003). Models of Ethnomedicinal Healing. Ethnomedicine Conferences, April 26-27 and October 11-12, Munich, Germany.

Kumar, A. (2013). Ethno botanical study of wild vegetables used by rural communities of Kannauj distric, Uttar Pradesh, India. Emirates Journal of Food and Agriculture, 25 (10) : 760-766.

Lamba, R. and Mehta, S. (1995). Priorities in Indian Medicine. A Tribal Perspective. Indian Anthropologist, $25: 1$ $-12$
Pei, S. (2001). Ethnobotanical approaches of traditional medicine studies some experiences from Asia. Pharama Bio. 39: 74-79.

Ratna, R.S. and Pirata, R.S. (2007). Socio-Ecology and religious affiliation in three Himalayan villages : Implications for mental health. Journal of the Indian Academy of Applied Psycology, 33 (1) : 23-30.

Sharma, V. and Joshi, B.D. (2010) Role of sacred plants in religion and health care system of local people of Almora District of Uttarakhand State (India). Academic Arena, 2 (6) : 19-22.

Shrestha, K. (1998). Ethnobotanical inventory and plant taxonomy: basic approaches for ethnobotanical research: Ethnobotany for conservation and community Development. Ethnobotanical Society of Nepal, 58-65.

Singh, K.R. and Singh, A. (2008) Indigenous healthcare practices in vogue among rural woman. Journal of Medicinal and Aromatic Plant Sciences, 30 : 399-405.

Tiwari, D.N. (1999) Medicinal plants for healthcare. Yojana, Volume, June : 8-17

WHO (2003). Diet, nutrition and prevention of chronic diseases. Report of the Joint WHO/FAO Expert Consultation. Geneva, World Health Organisation (WHO). Technical Report Series, No. 916. 